\title{
Erkeklerde Benlik Kavramının Netliğinin Mutlak Gerçek İhtiyacı ile Problem Çözme ve Stres Belirtileri Değişkenleri Arasındaki İlişkideki Aracılık Rolünün İncelenmesi
}

\author{
Investigation of the Mediator Role of Self Concept Clarity on The Relationship \\ Between Need for Absolute Truth and Problem Solving and \\ Symptoms of Stress in Men
}

\author{
Gizem AKCAN* \\ Erdinç ÖZTÜRK ${ }^{* *}$
}

$\ddot{O}_{z}$ : Bireylerin benlik keşfi aşamasında benliklerine ilişkin mutlak bilgiler edinmek istedikleri görülmektedir. Kendilerine ilişkin mutlak bilgi edinmek isteyen kişilerin yüksek düzeyde soyut kendini analiz eğilimlerinin olduğu belirtilmekte ve benliğin veya kişisel deneyimin arkasında yer alan gerçeklik ve aşırı genel, üst düzey, her durumda geçerli gerçeklik olmak üzere benliğe ilişkin üst düzey temsillerden birisi olan bu eğilim "mutlak gerçek ihtiyacı" (MGİ) olarak tanımlanmaktadır. Mutlak gerçek ihtiyacının yüksek olduğu kişilerin kendilerine ilişkin mutlak bilgi elde etmek adına arayışa girdiklerinde, benlik kavramlarının netliğinin azaldığı görülmektedir. Benlik kavramının netliği düşük olan bireylerin de problem çözme konusunda sorun yaşadıkları ve yoğun stres belirtileri gösterdikleri gözlemlenmektedir. Benlik kavramının netliği yüksek olan bireylerin yaşadıkları problemler karşısında daha sağlıklı başa çıkma stratejileri kullandıkları savunulmaktadır. Bu çalışmanın amacı, erkek bireylerde mutlak gerçek ihtiyacı değişkeninin stres belirtileri ve problem çözme becerileri değişkenleri üzerindeki etkisinde benlik kavramının netliği değişkeninin aracı rolünün incelenmesidir. Çalışmanın katılımcılarını, 20-50 yaş arasındaki 200 erkek birey oluşturmaktadır. Verilerin toplanmasında Demografik Bilgi Formu, Benlik Kavramının Netliği Ölçeği, Mutlak Gerçek İhtiyacı Ölçeği, Stres Belirtileri Ölçeği ve Problem Çözme Envanteri kullanılmıştır. Araştırmanın bulgularına göre, erkeklerde benlik kavramının netliği değişkeni mutlak gerçek ihtiyacı ile stres belirtileri ve problem çözme değişkenleri arasındaki ilişkide aracı değişken rolü oynamaktadır.

Anahtar sözcükler: Benlik Kavramının Netliği, Mutlak Gerçek İhtiyacı, Stres Belirtileri, Problem Çözme

Abstract: People try to find absolute knowledge about the concept of self during identity exploration. Individuals have a high propensity to engage in abstract self-analysis that aims at capturing absolute knowledge about the self. The motive for this is defined as "the need for absolute truth" (NAT). NAT refers to one of the highest level representations concerning the self: the truth beyond the self or personal experiences, a truth that is overgeneralized, superordinate and valid in all contexts. If people who have a high need for absolute truth try to have absolute knowledge about themselves, the clarity their self concept decreases. Individuals who have a low self concept clarity have problems in problem solving and exhibit a high level of stress. People who have a higher self concept clarity use healthier coping strategies for problem solving. The purpose of this study is to show the mediator role of the clarity of the self concept on the relationship between the need for absolute truth and problem solving and symptoms of stress in men. The participants in this study were 200 men whose ages varied between 20 and 50. A Demographic Information Form, Self Concept Clarity Scale, Need for Absolute Truth Scale, Stress Self-Assessment Checklist and Problem Solving Inventory were employed. According to the findings from this study, the concept clarity has the mediator role in the relationship between need for absolute truth and problem solving and the symptoms of stress in men.

Keywords: Self Concept Clarity, Need for absolute Truth, Problem Solving, Symptoms of Stress

\footnotetext{
* Dr. Öğr. Üyesi, Bartın Üniversitesi, Edebiyat Fakültesi, Psikoloji Bölümü,Bartın. gakcan@bartin.edu.tr

*** Prof., İstanbul Üniversitesi-Cerrahpaşa,Adli Tıp Enst., Sosyal Bilimler ABD, İstanbul. erdincerdinc@hotmail.com
} 
Bireylerin kimlik gelişimi ve benlik keşfi aşamasında benliklerine ilişkin mutlak bilgiler elde etmek istedikleri görülmektedir. Şimşek (2013), kendilerine ilişkin mutlak bilgi edinmek isteyen kişilerin yüksek düzeyde soyut kendini analiz eğilimlerinin olduğunu belirtmekte ve benliğin veya kişisel deneyimin arkasında yer alan gerçeklik ve aşırı genel, üst düzey, her durumda geçerli gerçeklik olmak üzere benliğe ilişkin üst düzey temsillerden birisi olan bu eğilimi "mutlak gerçek ihtiyacı" (MGI) olarak tanımlamaktadır. Bireyler ilk olarak "Gerçekten ben kimim?", "Davranışlarımın arkasındaki nedenler neler?" gibi sorulara cevap aramaya başlayarak benliklerini keşfederler. Yüksek MGİ sahibi olan bireylerin de kendilerine ilişkin daha üst düzey, soyut ve her durumda geçerli bilgiler elde etme amacı taşımaları nedeniyle benlik kavramlarının netliğinin düşük olduğu düşünülmektedir (Akcan, 2013).

$\mathrm{Bu}$ bağlamda, benliğini kabullenen ve benlik kavramı net olan bireylerin de daha az stres belirtisi göstereceği söylenebilir (Campbell et al. 1996; Slotter et al. 2010). Bunlara paralel olarak Akcan (2013) da, kendilerine çok fazla odaklanan bireylerin patoloji ile ilişkili olan MGİ nedeniyle özellikle problem çözme ve stresle başa çıkma konularında sıkıntı yaşadıklarını belirtmektedir. Kimlik keşfi süresince MGİ seviyeleri yüksek olan bireylerin benlik kavramlarının netliğinin düşük olduğu ve bu durumun da bireylerin ruh sağlığının olumsuz yönde etkilenmesine yol açarak stres belirtilerinde artışa ve problem çözme becerileri konularında sıkıntılara yol açtığı düşünülmektedir. Bu nedenle, MGİ ile stres belirtileri ve problem çözme becerileri arasındaki ilişkide benlik kavramının netliğinin rolünün ortadan kaldırılması durumunda MGİ ile stres belirtileri ve problem çözme becerileri arasındaki ilişkide düşüş gözleneceği düşünülmektedir. $\mathrm{Bu}$ doğrultuda bu çalışmada, erkeklerde MGİ ile problem çözme ve stres belirtileri değişkenleri arasındaki ilişkide benlik kavramının netliğinin aracı rolü incelenmiştir.

\section{Alanyazın Taraması}

\section{Benlik Kavramının Netliği}

Campbell, Trapnell, Heine ve Katz (1996) benlik kavramının netliği kavramını (self concept claritiy), bireylerin kendilerine ilişkin bilgilerinin açıkça tanımlanmış, içsel olarak tutarlı ve kalicı olması olarak tanımlamaktadır. Campbell ve arkadaşları (1996), benlik kavramının netliğinin yüksek olduğu kişilerin psikolojik iyi oluşlarının daha fazla olduğunu; benlik kavramının netliğinin düşük olduğu kişilerin ise depresyon ve nevrotiklik seviyelerinin daha yüksek olduğunu savunmaktadırlar. Bunların yanı sıra, kişinin kimliği hakkında yaşadığı belirsizliklerin genellikle güçlü duygularla (Bar-Anan et al. 2009) ve psikolojik uyumsuzluk ile ilişkili olduğu düşünülmektedir (Luyckx et al. 2008). Kimlik gelişimi sürecinde gerçekleşen kimlik keşfinin psikolojik strese yol açtı̆̆ 1 bilinmektedir (Berman et al. 2004).

Smith, Wethington ve Zhan (1996) da, benlik kavramının netliğinin düşük olmasının pasif başa çıkma mekanizmaları kullanma gibi birçok konuda olumsuz etkilerinin bulunduğunu belirtmektedirler. Leite ve Kuiper'e (2008) göre, benlik kavramının netliği düşük olan bireyler problemli düşüncelerini, duygularını ve davranışlarını tanımlamayı ve anlamayı daha zor bulmaktadırlar. Ayrıca yazarlar, benlik kavramının netliği konusunda sıkıntı yaşayan bireylerin harekete geçmeden önce farkındalıklarını ve iç görülerini artırmak adına daha fazla derin düşünce içinde bulunduklarını savunmaktadır; ancak, benlik kavramının netliğinin yüksek olduğu bireylerin davranışlarına, düşüncelerine ve duygularına ilişkin problemleri daha net anladıkları görülmektedir (Leite \& Kuiper 2008). Bunların yanı sıra yazarlar, benlik kavramının netliğinin düşük olduğu bireylerin, kendi özellikleri ve yetenekleri konusunda emin ve net olmadıklarını ve problemler karşısında uygun çözüm yollarını bulup uygulama hususunda umut düzeylerinin düşük olduğunu belirtmektedir. Hanna (2002) da, benlik kavramının netliğinin bireylerin 
değişimin gerekliliği duygusunu etkilediğini savunmaktadır. Bunlara ek olarak Prochaska ve DiClemente (1983), benlik kavramının netliği düşük olan kişilerin, davranışları, düşünceleri, duyguları, ilişkilerindeki ve çevrelerindeki rolleri net olmayan kişiler olduklarını belirtmekte ve kişisel değişimin duyguları, davranışları, düşünceleri ve rolleri üzerindeki etkilerini hayal edemediklerini savunmaktadır.

\section{Mutlak Gerçek İhtiyacı}

Bireylerin kimlik gelişimi ve benlik keşfi aşamasında benliklerine ilişkin mutlak bilgiler elde etmek istedikleri görülmektedir. Şimşek (2013), kendilerine ilişsin mutlak bilgi edinmek isteyen kişilerin yüksek düzeyde soyut kendini analiz eğilimlerinin olduğunu belirtmekte ve benliğin veya kişisel deneyimin arkasında yer alan gerçeklik ve aşırı genel, üst düzey, her durumda geçerli gerçeklik olmak üzerebenliğe ilişkin üst düzey temsillerden birisi olan bu eğilimi "mutlak gerçek ihtiyacı" (MGI) olarak tanımlamaktadır. Mutlak gerçek, belirsiz, somut bir kaynağ olmayan bilgiye dayanır ve görecelidir. Mutlak gerçeğin kişiden kişiye göre değişebilmesi nedeniyle, MGİ'nin soyut düşünceyi içerdiği söylenebilir.

Watkins'e göre (2008), kendine odaklanma olaylara ve durumlara ilişkin soyut düzeyde yapılar içeriyorsa zararlı olabilir; ancak somut düzeydeki yapılar zihinsel sağlı̆̆ etkileyen yapıcı sonuçlara sahiptir. Stöber, Tepperwien ve Staak'a göre (2000) de, soyutluk farklı durumlara genellenebilen ve belirsiz yapılar içermekte; somutluk ise durumlara özgü ve belirli yapılardan oluşmaktadır. Benzer şekilde Şimşek (2013) de, MGİ'nin psikopatoloji ile pozitif, zihinsel sağlık ile ise negatif yönde ilişkili olduğunu savunmaktadır.

Ayrıca Akcan (2013), kişinin kendisine ilişkin mutlak gerçeğe ulaşmak adına sürekli kendini analiz edebileceğini, kendi hakkında farklı bilgiler elde etmek için çaba sarf edebileceğini ve kendinin olumsuz, yetersiz yönlerini keşfedebileceğini savunmaktadır. Sürekli bilgi edinme arayışında olmanın, kafa karışıklığına yol açarak kaygı yaratabileceği ve aynı zamanda, kişinin kendisinin olumsuz ve negatif yönlerini görmesinin kişide yetersizlik hissi uyandırarak depresyona yol açabildiği belirtilmektedir (Şimşek,2013). Bu doğrultuda, benliklerine ilişkin somut, net bilgiler arayan ve MGİ seviyeleri yüksek olan bireylerin kimlik karmaşası yaşadıkları söylenebilir. Bu karmaşa karşısında problem çözme yöntemi olarak kendilerine çok fazla odaklandıkları, duygu ve davranışlarına ilişsin daha fazla bilgi edinmek için farklı kaynaklara yönelebildikleri görülmektedir (Akcan,2018).

\section{Benlik Kavramının Netliği ile MGİ Değişkeni Arasındaki İlişski}

Şimşek (2013) MGİ'yi, kişinin kendisi hakkındaki değişmez, sabit ve kesin bilgiler bulma konusundaki bitmeyen arayışı olarak tanımlamaktadır. Yazar, bu sürecin mutlak gerçek ile ilgili sonsuz sayıda olası ilişkinin bulunması nedeniyle hayal kırıklıklarına ve içsel çatışmaya yol açtığını savunmaktadır. Campbell et al. (1996) tarafından düzenlenen çalışmada, kendine odaklanmanın benlik kavramının netliği ile negatif yönde ilişkili olduğu bulunmuştur. Bu bilgiyi destekler şekilde Şimşek (2013) tarafindan düzenlenen çalışmada da, MGİ'nin depresyon ve kaygı gibi zihinsel sağlık ile ilişkili problemlerle pozitif, benlik saygısı, benlik kavramının netliği ve iç görü gibi olumlu zihinsel sağlık belirtileri ile ise negatif yönde ilişkili olduğu bulunmuştur. Butzer ve Kuiper (2006) de, kişinin benliğine ilişkin çelişkilerinin fazla olmasının belirsizliğe tahammülsüzlük nedeniyle kişinin kendiyle ilgili gerçeği arama eğilimini artırdığını savunmaktadır.

MGİ, kişinin benliğiyle veya kişisel deneyimleriyle ilgili aşırı genellenmiş, üst düzey ve her durumda geçerli temsillerini yansıtmaktadır (Şimşek 2013). Watkins (2008), yüksek seviyede kendine odaklanmanın davranışlar veya anlamlar için genel, üst seviyede ve bağlamından ayrı 
kurallar bulmak adına aşırı genelleme yapma eğilimini artıracağını savunmaktadır. Watkins (2008) tarafindan belirtilen üst düzey temsillerin olumsuz sonuçları MGI' ye de uygulanabilir. Ayrıca Nisbett ve Wilson (1977), üst düzey temsillere odaklanmanın kişilerin olaylara tüm durumlara uygulanamayan genel teoriler veya yaygın inançlar açısından bakma eğilimini artırdığını belirtmekte ve bu durumun da benlik saygısı, iç görü ve benlik kavramının netliği ile negatif yönde ilişkili olan azalmış iç görüye yol açtığını savunmaktadır.

Düzenlenen çalışmalarda, MGİ'nin benlik kavramının netliği ve iç görüyle olan ilişkisi açısından zihinsel sağllğı olumsuz yönde etkilediği görülmüştür (Akcan 2013). Kişilerin, kendileri hakkında mutlak bilgiler edinmek adına kendileri üzerine tekrar tekrar düşünerek soyut düşünme tarzı içine girebildikleri ve soyut düşünme tarzının da depresyon gibi birçok psikopatoloji unsuru ile ilişkili olduğu belirtilmektedir (Şimşek 2013). Ayrıca, kendiyle ilgili daha fazla, kesin ve her durumda geçerli mutlak bilgiler edinme ihtiyacı taşıan bireyler kendilerine çok fazla odaklanarak kendileri hakkında yeni bilgiler elde edebilirler ve elde ettikleri bilgilerin birbiriyle çeliştiğini görmeleri durumunda da benlik kavramlarının netliği azalabilir. Çünkü MGİ soyut düşünme tarzını içerir ve bu düşünme tarzında da durumlara özgü farklı bilgiler yerine her duruma genellenebilen bilgiler mevcuttur ancak, kişinin gerçek benliğine ve davranışlarının arkasındaki nedenlere ilişkin durumsal farklılıklar söz konusudur. Bireyler farklı durumlarda farklı davranışlar gösterebilir veya aynı davranış farklı durumlarda farklı nedenlerden kaynaklanıyor olabilir. Kendisine ilişkin her durumda geçerli mutlak bilgiler edinme konusunda başarısızlık yaşayan kişinin benlik kavramının netliği de düşebilir. Akcan (2018) bu nedenle, MGİ değişkeni ile benlik kavramının netliğini değişkeni arasında negatif yönde bir ilişki olduğunu belirtmektedir.

\section{Benlik Kavramının Netliği ile Problem Çözme ve Stres Belirtileri Değişkenleri Arasındaki İlişki}

Benlik kavramı, kişinin kendisi hakkındaki bilgileri organize eden ve işleyen bilişsel şemayı tanımlar (Campbell 1990). Yazara göre, benlik kavramının netliği de benlik kavramının yapısal bir parçasıdır ve kişinin kendisi hakkındaki bilgilerin açık ve net bir şekilde tanımlanması, içsel olarak tutarlı olması ve sabit olmasıdır. Ayrıca benlik kavramının netliği, benlik saygısı ve depresyon ile de ilişkilidir (Lee-Flynn et al. 2011). Smith, Wethington ve Zhan (1996) tarafindan düzenlenen çalışmada, benlik kavramının netliğinin plan yapma ve eyleme geçme gibi aktif başa çıkma stratejileri ile pozitif yönde anlamlı; fakat düşük düzeyde ilişkiye sahip olduğu, inkar gibi pasif başa çıkma yöntemleri ile ise negatif yönde güçlü bir ilişkiye sahip olduğu görülmektedir.

Bunların yanı sıra, stresli olaylarla başarılı bir şekilde baş etmenin psikolojik iyi oluş açısından oldukça önemli olduğu savunulmaktadır (Ed et al. 1999). Başarılı bir şekilde başa çıkmanın sosyal destek gibi hem kişilerarası ve dişsal faktörlerle (Zhou et al. 2008), hem de kişisel özellikler ve psikolojik durum gibi kişisel ve içsel unsurlarla (Watson et al. 1999) ilişkili olduğu savunulmaktadır. Benlik kavramının netliğinin de kişisel unsurlardan biri olduğu bilinmektedir.

Campbell ve arkadaşları (1996) benlik kavramının netliğini hem bir kişisel özellik hem de bir durum olarak tanımlamaktadırlar. Conley (1984), benlik kavramının netliğinin geçici bir durum olduğunu belirtmekte, Nezlek ve Plesko (2001) de, çevresel faktörlerin etkisiyle dalgalanmaların meydana geldiğini savunmaktadır. Bunlara ek olarak, benlik kavramının netliğinin kayg1, olumsuz duygu durum ve düşünsel geviş getirme gibi psikolojik strese yol açan unsurlarla negatif yönde ilişkili olduğu savunulmaktadır (Slotter et al. 2010). Ayrıca, Ritchie, Sedikides, Wildschut, Arndt ve Gidron (2011) tarafindan düzenlenen çalışmada, benlik kav- 
ramının netliğinin kişilerin stres kaynağının benlik kavramı ile ilişkisini belirlemesine olanak sağlayarak optimum düzeyde psikolojik işlevselliği etkilediği görülmektedir. Ayrıca, benlik kavramının netliğinin artmasının ilişkisel doyumun artmasını sağladığ 1 belirtilmektedir (Lewandowski et al. 2010). Ed, Suh, Lucas ve Smith (1999) de, stres ile benlik kavramının netliği arasında negatif yönde bir ilişki olduğunu savunmaktadır.

Bunlara ek olarak Lee-Flynn ve arkadaşları (2011) tarafından düzenlenen çalışmada, benlik kavramının netliğinin bireylerin kişiler arası ilişkilerde yaşadığ 1 stresi değerlendirmesini etkilediği görülmüştür. Bilişsel değerlendirmelerin, bireylerin stresli olaylara nasıl tepki verdiği ve adaptasyonal sonuçları konularında oldukça etkili bir role sahip olduğu savunulmaktadır (Franks \& Roesch 2006). Cohen et al. (2005), olayları kontrol dışı, tehdit edici olarak algılayan veya stresli olaylara karşı olumsuz tepki veren bireylerin zaman içerisinde olumsuz duygu duruma sahip olacağını ve depresif belirtiler göstereceğini belirtmektedir.

Benlik kavramının netliği, bireylerin kendileri hakkındaki görüşlerinin açık ve kesin olarak tanımlanmış ve içsel olarak tutarlı olması olarak tanımlanmıştır (Campbell et al. 1996). Ayrıca Treadgold (1999), benlik kavramının netliğinin depresif semptomlar üzerinde belirleyici olduğunu savunmaktadır. Bunlara ek olarak, benlik kavramı net olan bireylerin stres yaratan olaylardan daha az etkilenmeleri ve olumsuz yargılamalarla başa çıkmada daha başarılı olmaları nedeniyle benlik kavramının netliğinin stres yaratıcı olaylar karşısında koruyucu bir görev gördüğü belirtilmektedir (Lee-Flynn et al. 2011). Örneğin; kendilerine ilişkin inançları net olan bireylerin karar vermede kendilerini rehber edindikleri, kesin olan inançları hakkında geri bildirim aldıkları ve kendilerine ilişkin inançlarını değiştirme konusunda daha dirençli oldukları savunulmaktadır (Swann et al. 1988). Ancak, benlik kavramının netliği düşük olan bireylerin kendilerine ilişkin görüşleri nasıl davranacakları konusunda onlara etkili ve tutarlı bilgi vermediğinden stres yaratan olaylara daha fazla tepki verdikleri dikkat çekmektedir (Kernis et al. 2000). Yapılan çalışmalara paralel olarak Constantino, Wilson, Horowitz ve Pinel (2006) de, benlik kavramının netliğinin stres sürecinde tampon görevi gördüğünü belirtmektedir.

\section{MGİ ile Problem Çözme ve Stres Belirtileri Değişkenleri Arasındaki İlişki}

Somut düşüncelerin, kişinin kendisi hakkındaki düşüncelerinin belirgin, duruma özgü, anlaş1ır, açık ve bireysel olmasi; diğer yandan soyut düşüncelerin ise belirsiz, tüm durumlar için geçerli ve şüpheli olduğu belirtilmektedir (Stober et al. 2000). Kişinin kendisi hakkındaki gerçekleri bulma eğilimi (MGI), kendine odaklanmanın soyut şekli ve tüm durumlarda geçerli benliğin üst düzey temsilleri olarak tanımlanmaktadır. Kişinin benliğine ilişkin genel, üst düzey ve bağlamın dışında gerçekleri bulma isteğinin kişinin kendisini çevreye adapte etmesini zorlaştırdığı savunulmaktadır (Şimşek et al. 2013). Şimşek (2013), yüksek seviyedeki MGI'nin davranışlar ve anlamlar hakkında genel, üst düzey ve bağlamın dışında kurallar bulmak için aşırı genelleme yapma eğilimini artırdığını belirtmektedir.

Bunlara ek olarak Şimşek (2013), yüksek MGİ'nin her duruma ilişkin esas bir açılama veya anlam bulmak için zarar verici bir ihtiyaç olması nedeniyle kişiler arası ve kişisel seviyede problem çözümünü engellediğini belirtmektedir. Nisbet ve Wilson (1977) da, yüksek seviyedeki temsillere odaklanmanın, kişilerdeki durumlara genel teorilerle veya yaygın hesaplarla yaklaşma eğilimini artırdığını ve iç görüyü azalttığını belirtmektedir. Her olayın kendine özgü bir dinamiği olması nedeniyle olaylara genel teorilerle yaklaşmanın işlevsel olmayabileceği söylenebilir. Bu doğrultuda, bireylerin yüksek MGİ taşımaları nedeniyle kişisel ve kişiler arası durumlarda problem çözmede zorluk çektikleri düşünülebilir. Problem çözümünde sıkıntı yaşayan bireylerde de depresyon, intihar, kaygı, stres gibi rahatsızlıklara sıklıkla rastlanabileceği söylenebilir. 
MGİ nedeniyle kendine aşırı odaklanan kişiler, benlikleri hakkında olumsuz bilgiler elde ettiklerinde ve olumsuzlukları zihinlerinde defalarca düşündüklerinde olumsuz duygu ve düşünceleri tekrar yaşayabilir. Bu da kişilerin stres düzeyinin artmasına yol açarak psikolojik sağlıklarına zarar verir (Akcan 2013). Psikolojik sağlığı zarar gören bireylerin stresle başa çıkma ve problem çözme becerilerinin de olumsuz yönde etkilendiği bilinmektedir (Sardoğan et al. 2006). Ayrıca, ruh sağlığı üzerinde olumsuz etkisi olduğu düşünülen MGİ'nin bireylerin stresle başa çıkma ve problem çözme becerilerini de olumsuz yönde etkilediği düşünülmektedir.

Watkins'e (2008) göre, soyut yapılar problem çözme yeteneği, kendini düzenleme ve depresyon gelişimi üzerine üç temel olumsuz etkiye sahiptir. Şimşek (2013) de, bu üç ana olumsuz etkinin MGİ için de geçerli olabileceğini belirtmektedir. Yazar öncelikle, üst seviyedeki MGİ'nin, davranışlar ve anlamlar için genel, üst düzey ve durumdan bağımsız kurallar bulmak adına aşırı genelleme yapma eğilimini artırdığını savunmaktadır. İkinci olarak, yüksek MGİ taşıyan kişiler için kendini düzenlemenin zor olduğu, çünkü Watkins'in (2008) de belirttiği gibi kendini düzenlemenin somut düşünce ve şimdiki durumun ihtiyaçlarına odaklanmadan yararlandığı belirtilmektedir. MGI'de ise, şimdiki anla ilgili bilgiden ziyade genel ve her durumda geçerli bilgi önemlidir. Son ve en önemli olarak, yüksek MGİ, her duruma özgü esas bir açıklama veya anlam bulmak için zarar verici bir ihtiyaç olarak kişiler arası ve kişisel seviyede problem çözümünü engellemektedir (Şimşek 2013).

Bunlara paralel olarak Watkins ve Teasdale (2004), zihinsel sağlik için kişinin kendi deneyimlerine daha az analitik şekilde odaklanmasının anlamlara ve nedenlere soyut şekilde odaklanmaktan daha yararlı olduğunu belirtmektedir. Ayrıca Watkins (2008), olaylara ve eylemlere yönelik soyut yapılar içermesi durumunda kendine odaklanmanın zihinsel sağlık açısından zarar verici olduğunu savunmaktadır. Bu bağlamda MGİ, davranışlara ve anlamlara yönelik gerçekleri bulmak için soyut düşünme tarzını içerdiğinden zihinsel sağlık üzerinde olumsuz etkiye sahiptir denilebilir. MGİ'nin stres belirtileri ile pozitif, problem çözme becerileri ile ise negatif yönde ilişkili olduğu düşünülebilir.

\section{MGİ ile Problem Çözme ve Stres Belirtileri Değişkenleri Arasındaki İlişkide Benlik Kav- ramının Netliğinin Aracılık Rolü}

Bireylerin kimlik gelişimi ve benlik keşfi aşamasında benliklerine ilişsin mutlak bilgiler elde etmek istedikleri görülmektedir. Benlik keşfi süresince benliklerine ilişkin genel, her durumda geçerli ve kesin bilgiler elde etmek isteyen bireylerin MGI'nin yüksek olduğu düşünülebilir. Yüksek MGİ taşıyan kişilerin kendilerine ilişkin mutlak bilgi elde etme arayışına girdiklerinde, benlik kavramları hususunda kafa karışıklığı yaşayacakları, benlik kavramlarının netliğinin azalacağı ve asıl benlikleri ile mutlak benlikleri arasında daha çok farklılık algılayacakları söylenebilir.

Bu bağlamda, benlik keşfi süresince yüksek MGİ sahibi olan bireylerin yüksek stres belirtileri göstermesinde ve problem çözme becerilerinin düşük olmasında benlik kavramlarının netliğinin düşük olmasının etkisinin olduğu düşünülebilir. MGİ nedeniyle kendilerine çok fazla odaklanan bireylerin edindikleri bilgilerin durumlara özgü farklılıklar göstermesi nedeniyle benliklerine ilişkin çelişki yaşayabilecekleri ve benlik kavramlarının netliğinin azalacağı söylenebilir. Benlik kavramının netliği düşük olan bireylerin de problem çözme konusunda sıkıntı yaşadıkları ve stres belirtilerinin artığı bilinmektedir (Campbell et al. 1996). Cass (1979) da, benlik kavramı net olan bireylerin stres yaratan durumlarla karşılaştıklarında stres yönetiminde daha başarılı olduklarını belirtmektedir.

Bu bağlamda, MGİ ile stres belirtileri ve problem çözme becerileri arasındaki ilişkide benlik 
kavramının netliği değişkeninin rolünün ortadan kaldırılması durumunda MGİ ile stres belirtileri ve problem çözme becerileri arasındaki ilişkinin istatiksel olarak anlamsızlaşacağ 1 düşünülmektedir. Özetle, benlik kavramının netliği değişkeninin etkisi nedeniyle MGİ'nin stres belirtilerini ve problem çözme becerilerini etkilediği düşünülmektedir. Bunlara ek olarak, şimdiye kadar düzenlenen çalışmalarda kadınların benlik kavramlarının netliğinin erkeklerden daha düşük olduğu bulunmuştur (Campbell et al. 1996; Pinquart \& Sörensen 2001). Bu nedenle bu çalışmanın örneklem grubunu kadınlarla kıyaslandığında benlik kavramının netliğinin daha yüksek olduğu düşünülen erkekler oluşturmaktadır. Bu çalışmanın amacı, erkeklerde MGİ ile problem çözme ve stres belirtileri değişkenleri arasındaki ilişkide benlik kavramının netliği değişkeninin aracı rolünün incelenmesidir.

Araştırmanın alt problemleri şu şekildedir:

1. Erkeklerde MGİ, problem çözme ve stres belirtileri değişkenlerini yordamakta mıdır?

2. Erkeklerde MGİ, benlik kavramının netliği değişkenini yordamakta mıdır?

3. Erkeklerde benlik kavramının netliği problem çözme ve stres belirtileri değişkenlerini yordamakta midır?

\section{Yöntem}

\section{Araștırmanın Modeli}

$\mathrm{Bu}$ çalışma, niceliksel bir çalışma olup, betimleyici desen kullanılmıştır. Betimsel modelde, bir konu hakkındaki mevcut durum araştırılır ve betimsel araştırmaların, öz aktarım araştırmaları ve gözlem araştırmaları olmak üzere iki şekilde düzenlenebildiği bilinmektedir. Özdamar (1999), öz aktarım çalışmalarının verilerinin anketler vasıtasıyla yazılı olarak veya görüşmeler yoluyla sözlü olarak örneklemde yer alan bireylerin kendilerinden bilgi alınarak toplandığını belirtmektedir. Bu çalışmada da katılımcılara ölçeklerin verilmesi ile bilgi toplanmıştır.

\section{Evren ve Örneklem}

Şimdiye kadar düzenlenen çalışmalarda kadınların benlik kavramlarının netliğinin erkeklerden daha düşük olduğu bulunmuştur (Campbell et al. 1996; Pinquart \& Sörensen 2001). Bu nedenle bu çalışmanın örneklem grubunu kadınlarla kıyaslandığında benlik kavramının netliğinin daha yüksek olduğu düşünülen erkek bireyler oluşturmaktadır. Bu çalışmanın evrenini, İstanbul ve Kocaeli illerinde yaşayan, en az lise ve üniversite düzeyinde eğitim görmüş, 20-50 yaş arası 200 erkek birey oluşturmaktadır. Araştırmanın örneklemi ise, İstanbul ve Kocaeli illerinde yaşayan en az lise ve üniversite düzeyinde eğitim görmüş 200 erkek bireyden oluşmaktadır. Örnekleme işlemi, evreni temsil erkek bireyler arasından gönüllülük esası göz önünde bulundurularak kolayda örnekleme Yöntemi ile gerçekleştirilmiştir. Kolayda örnekleme, ana kütle içerisinden seçilecek örnek kesimin araştırmacının yargılarınca belirlendiği tesadüfî olmayan örnekleme yöntemidir. Kolayda örneklemede veriler, ana kütleden en kolay, hızlı ve ekonomik şekilde toplanır (Malhotra 2004).

\section{Kullanılacak Ölçme Araçları}

$\mathrm{Bu}$ çalışmada, ilk olarak katılımcılara araştırmacı tarafından geliştirilen Demografik Bilgi Formu uygulanmıştır. Ardından, katılımcılara uygulanan Benlik Kavramının Netliği Ölçeği, Mutlak Gerçek İhtiyacı Ölçeği, Stres Belirtileri Ölçeği ve Problem Çözme Envanteri ile veriler toplanmıştır. 


\section{Demografik Bilgi Formu}

Araştırmacı tarafından geliştirilen demografik bilgi formu, katılımcıların yaş, eğitim düzeyi ve cinsiyetlerini belirlemeye yönelik sorulardan oluşmaktadır.

\section{Benlik Kavramının Netliği Ölçeği (BKNÖ)}

Benlik Kavramının Netliği Ölçeği, Campbell, Trapnell, Heine, Katz, Lavallee ve Lehman (1996) tarafından benlik kavramıyla ilgili inançların ne derece açık ve kesin bir bilgiye dayandığını ve benlik kavramını ne derece güvenilir bir şekilde tanımlandığını ölçmek amacıyla geliştirilmiştir. Ölçek, 5'li Likert tipi ölçeğe uygun olacak şekilde 1- Bana Hiç Uygun Değil, 2Bana Çok Az Uygun, 3- Bana Uygun, 4- Bana Oldukça Uygun, 5-Bana Tamamen Uygun şeklinde 1'den 5'e doğru puanlanmıştır puanlar daha düşük benlik kavramını belirtmektedir. Ölçek 12 maddeden oluşmaktadır ve tek boyutlu bir yapıdır. 7 ve 11 numaralı maddeler ters olarak puanlanan maddelerdir. Alpha güvenirlik katsayısı 0.86 olarak bulunmuştur. Ölçek, Sümer ve Güngör (1999) tarafından Türkçe' ye uyarlanmıştır ve Cronbach alpha güvenirlik katsayıs1 .89 olarak hesaplanmıştır. Bu çalışmada ise ölçeğin Cronbach Alpha güvenirlik katsayısı .84 olarak hesaplanmıştır. BKNÖ ile kurulan modeli daha iyi hale getirmek için 12 madde üç parsele ayrılmıştır. Parselleme yapmak için öncelikle düzeltilmiş madde toplam korelasyon değerleri hesaplanmıştır. Bu değerler büyükten küçüğe sıralanmış ve daha sonra sırası ile üç parsele, parsellerin toplam korelasyon değerleri birbiri ile dengeli olacak şekilde dağıtılmıştır. Madde yüklerine göre maddeler sıralandığında birinci parsel altında 4, 12, 1 ve 7 numaralı maddeler; ikinci parsel altında 3, 6, 9 ve 11 numaralı maddeler, üçüncü parsel altında ise 5, 2, 10 ve 8 numaralı maddeler yer almaktadır. Elde edilen uyum iyiliği değerleri ölçeğin dataya mükemmel uyum gösterdiğini belirtmektedir $\left(\chi^{2} / s d<2\right.$; RMSEA $<0.05$; CFI $>0.95$; IFI $>0.95$;

GFI $>0.95 ;$ SRMR $<0.05)$.

\section{Mutlak Gerçek İhtiyacı Ölçeği (MGïö)}

Şimşek (2013) tarafından katılımcıların kendileri hakkında mutlak gerçeği bulma ihtiyaçlarının seviyesini ölçmek amacıyla geliştirilmiştir. MGİ Ölçeği, 5 maddeden oluşmaktadır ve Likert tipi ölçeğe uygun olacak şekilde (1) - bana hiç uygun değil, (2) - bana çok az uygun, (3) - bana uygun (4) - bana oldukça uygun, (5) - bana tamamen uygun şeklinde 1' den 5' e doğru puanlanmıştır. Yüksek puanlar yüksek derecede MGİ olduğunu belirtmektedir. 5 soruluk MGİ Ölçeği için Cronbach Alpha iç tutarlık katsayısı .72 olarak hesaplanmıştır. Bu çalışmada ise ölçeğin Cronbach Alpha güvenirlik katsayıs1 .79 olarak hesaplanmıştır. MGiÖ ile kurulan modeli daha iyi hale getirmek için 5 madde iki parsele ayrılmıştır. Parselleme yapmak için öncelikle düzeltilmiş madde toplam korelasyon değerleri hesaplanmıştır. Bu değerler büyükten küçüğe sıralanmış ve daha sonra sırası ile iki parsele, parsellerin toplam korelasyon değerleri birbiri ile dengeli olacak şekilde dağıtılmıştır. Maddeler sıralandığında birinci parsel altında 3, 5 ve 2 numaralı maddeler; ikinci parsel altında 4 ve 1 ve numaralı maddeler yer almaktadır. Elde edilen uyum iyiliği değerleri ölçeğin dataya iyi uyum gösterdiğini belirtmektedir $\left(\chi^{2} / s d<2\right.$;

RMSEA $<0.05 ; \mathrm{CFI}>0.95 ;$ IFI $>0.95 ;$ GFI $>0.95 ;$ SRMR $<0.05$ ).

\section{Stres Belirtileri Ölçeği (SBÖ)}

Bu ölçek, stres durumundaki belirtilerin saptanması amacıyla 1992 yılında DasGupta tarafından geliştirilmiştir. Ölçek, 38 maddeden oluşan dört dereceli Likert tipi bir ölçme aracıdır (1= Hiç, $2=$ Ara sıra, 3=Sık sık, 4= Sürekli) Hovardaoğlu (1997) tarafından yapılan faktör analizi sonucunda ölçeğin; bilişsel-duyusal, fizyolojik ve ağrı yakınma olmak üzere 3 faktörden olu- 
ştuğu belirlenmiştir: Ölçeğin iki yarım test güvenirliğinin tüm faktörler için 0. 62- 0.73 arasında değiştiği bildirilmiştir.

Bu çalışmada erkek katılımcılar ile çalışıldığından adet sancılarına ilişkin soru ölçekten çıkartılarak ölçek 37 maddeye düşürülmüştür. Bu çalışmada ölçeğin Cronbach Alpha güvenirlik katsayıs1 0.92 olarak hesaplanmıştır. SBÖ ile kurulan modeli daha iyi hale getirmek için 37 madde üç parsele ayrılmıştır. Parselleme yapmak için öncelikle düzeltilmiş madde toplam korelasyon değerleri hesaplanmıştır. Bu değerler büyükten küçüğe sıralanmış ve daha sonra sırası ile üç parsele, parsellerin toplam korelasyon değerleri birbiri ile dengeli olacak şekilde dağıtılmıştır. Maddeler sıralandığında birinci parsel altında 27, 9, 29, 32, 28, 1, 2, 34, 23, 25, 11 , 21 ve 14 numaralı maddeler; ikinci parsel altında $8,36,3,15,20,37,26,13,18,10,22$ ve 12 numaralı maddeler, üçüncü parsel altında ise $35,16,33,24,19,31,30,17,4,6,7$ ve 5 numaralı maddeler yer almaktadır. Elde edilen uyum iyiliğideğerleri ölçeğin dataya iyi uyum gösterdiğini belirtmektedir $\left(\chi^{2} / s d<2\right.$; RMSEA $<0.05$; CFI $>0.95$; IFI $>0.95$;GFI $>0.95$; $\left.\mathrm{SRMR}<0.05\right)$

\section{Problem Çözme Envanteri (PÇE)}

Problem çözme envanteri (PÇE) bireyin problem çözme becerileri konusunda kendini algılayışını ölçmeye yönelik bir envanterdir. Ölçek 35 maddeden oluşmaktadır. 1-6 arası puanlanan Likert tipi bir ölçektir. Ölçek Heppner ve Petersen (1982) tarafından geliştirilmiştir. Ölçeğin, "Problem çözme yeteneğine güven", "yaklaşma-kaçınma" ve "kişisel kontrol" olmak üzere üç faktörden oluştuğu belirtilmektedir. Bu üç faktör arasındaki korelasyon ranjı ise 0.38 ile 0.49 arasında değişmektedir (Savaşır \& Şahin 1997).

Ölçeğin Türkçeye uyarlama çalışması Şahin, Şahin ve Heppner (1993) tarafindan yapılmıştır. Ölçeğin güvenirlik çalışmasında Alfa değeri 0.88 olarak bulunmuştur. Yapılan faktör analizinde "Aceleci Yaklaşım", "Düşünen Yaklaşım", "Kendine Güvenli Yaklaşım", "Kaçıngan Yaklaşım, "Değerlendirici Yaklaşım", "Planlı Yaklaşım" olmak üzere altı faktör bulunmuştur (Savaşır \& Şahin 1997). Düzenlenen çalışmada, ölçeğin Cronbach Alpha güvenirlik katsayısı 0.89 olarak hesaplanmıştır. PÇE ile kurulan modeli daha iyi hale getirmek için 35 madde üç parsele ayrılmıştır. Parselleme yapmak için öncelikle düzeltilmiş madde toplam korelasyon değerleri hesaplanmıştır. Bu değerler büyükten küçüğe sıralanmış ve daha sonra sırası ile üç parsele, parsellerin toplam korelasyon değerleri birbiri ile dengeli olacak şekilde dağıtılmıştır. Maddeler siralandığında birinci parsel altında 27, 23, 4, 18, 5, 25, 3, 19, 17, 8 ve 32 numaralı maddeler; ikinci parsel altında $24,11,20,2,14,21,12,6,30,7$ ve 33 numaralı maddeler, üçüncü parsel altında ise 34, 28, 10, 26, 15, 35, 31, 16, 1 ve 13 numaralı maddeler yer almaktadır.

Elde edilen uyum iyiliği değerlerin ölçeğin dataya iyi uyum gösterdiğini belirtmektedir ( $\chi^{2} / s d<2$; RMSEA $<0.05 ; \mathrm{CFI}>0.95 ; \mathrm{IFI}>0.95$; GFI $>0.95$; $\mathrm{SRMR}<0.05$ ).

\section{Verilerin Toplanması}

Örneklemde yer alan katılımcılar, kolayda örnekleme yöntemi ile gönüllülük esası göz önünde bulundurularak İstanbul ve Kocaeli illerinde yaşayan en az lise ve üniversite düzeyinde eğitim görmüş, 20-50 yaş aras1 erkek bireylerden oluşmaktadır.

Çalışmada yer alan anketler katılımcılara kağıt- kalem yöntemi ile katılımcılar İstanbul ilinde bulunan Psikolium Danışmanlık ve Koçluk Merkezi ve Kocaeli ilinde bulunan Özel Duygum Özel Eğitim Merkezi'ne çağrılarak uygulanmıştır. 


\section{Verilerin İstatistiksel Analizi}

Çalışmada elde edilen bulgular değerlendirilirken, demografik bilgilere ilişkin verilerin analizinde SPSS (Statistical Package for Social Sciences) for Windows 22.0 programı kullanılmıştır. Doğrulayıcı Faktör Analizi ve Yapısal Eşitlik Modeli için ise Lisrel 8.80 programı kullanılmıştır.

Bu çalışmada ilk olarak, aşamalı yaklaşımın gereği olarak modeli test etmeden önce ölçme modeli test edilmiştir. Daha sonra, benlik kavramının netliği ile problem çözme ve stres belirtileri değişkenleri arasındaki ilişki, MGİ ile benlik kavramının netliği değişkeni arasındaki ilişki, MGİ ile problem çözme ve stres belirtileri değişkenleri arasındaki ilişki analiz edilmiştir.

İki değişken arasındaki sebep-sonuç ilişkisini etkileyebilecek nedenlerden birisi üçüncü bir değişkenin bu ilişkide aracı değişken rolü oynamasıdır. Bu çalışmada, benlik kavramının netliği değişkeninin aracı rolü oynadığ 1 düşünülmektedir. Bu nedenle, MGİ ile problem çözme ve stres belirtileri değiş̧kenleri arasındaki ilişkide benlik kavramının netliği değişkeninin aracı rolü analiz edilmiştir.

\section{Araştırmanın Bulguları}

\section{Örneklemin Demografik Dağılımı}

Tablo 1. Katılımcıların Sosyodemografik Özelliklerine İlişkin Tanımlayıcı Bulgular

\begin{tabular}{|l|l|l|l|}
\hline Değişkenler & 1.1 .1$. & $\mathbf{N}$ & $\mathbf{\%}$ \\
\hline \multirow{4}{*}{ Yaş } & 20 'den küçük & 13 & 6.5 \\
& $20-30$ & 119 & 59.5 \\
& $30-40$ & 46 & 23 \\
& $40+$ & 22 & 11 \\
\hline \multirow{4}{*}{ 1.1.2. } & 1.1 .3$. & 1.1 .5$. & 1.1 .7$. \\
& 1.1 .4$. & 1.1 .6$. & 1.1 .8$. \\
& Evli & 50 & 25 \\
\cline { 2 - 4 } & Bekar & 130 & 65 \\
& Boşanmiş & 7 & 3.5 \\
& Birlikte Yaşayan Çift & 12 & 6 \\
\hline \multirow{5}{*}{ Mĕitim Düzeyi } & Lise & 39 & 19.5 \\
\cline { 2 - 4 } & Üniversite & 91 & 45.5 \\
\cline { 2 - 4 } & Lisans Üstü & 70 & 35 \\
\hline & Memur & 39 & 19.5 \\
& İşsiz & 20 & 10 \\
\cline { 2 - 4 } & Serbest Meslek & 17 & 8.5 \\
& Özel Sektör & 56 & 28 \\
& Öğrenci & 46 & 23 \\
\cline { 2 - 4 } & Diğer & 21 & 10.5 \\
\hline
\end{tabular}

Çalışmaya katılan erkek bireylerin, \%6.5'i 20 yaşından küçük, \%59.5'i 20-30 yaş arası, \%23'ü 30-40 yaş arası, \%11'i ise 40 yaşın üzerindedir. Katılımcıların \%25'i evli, \%65'i bekar, \%3.5'i boşanmış, \% 6'sı birlikte yaşayan çifttir. Bireylerin \%9.5' i lise, \% 45.5' i üniversite, \% 35'i lisansüstü mezunudur. Ayrıca, bireylerin \%19.5' i memur, \% 23'ü öğrencidir. \%8.5' i serbest meslek, \%28'i özel sektör, \% 10.5' i diğer sektör çalışanıdır. \%10’u ise işsizdir (Tablo 1.). 
Tablo 2. Katılımcıların Mutlak Gerçek İhtiyacı Ölçeği, Benlik Kavramının Netliği Ölçeği, Stres Belirtileri Ölçeği ve Problem Çözme Envanterlerinde Aldıkları Puanların Dağılımı (Ranj), Ortalaması $(\mathrm{X} \overline{)}$, ve Standart Sapması (S)

\begin{tabular}{|c|c|c|c|c|c|c|}
\hline 1.1.9. & 1.1 .10 . & 1.1 .11$. & Erkekler $(\mathrm{N}=\mathbf{2 0 0})$ & $\begin{array}{l}1.1 .12 . \\
1.1 .13 .\end{array}$ & 1.1 .14 . & 1.1.15. \\
\hline $\begin{array}{l}\begin{array}{l}\text { Mutlak Gerçek İhtiyacı } \\
\text { Ölçeği }\end{array} \\
\end{array}$ & $\begin{array}{c}1.1 .16 . \\
\text { Puan Dağılımı } \\
\end{array}$ & 1.1 .17 . & $\begin{array}{c}1.1 .18 \\
5-25\end{array}$ & 1.1 .19$. & 1.1.20. & 1.1.21. \\
\hline 1.1.22. & $\bar{X}$ & & 14.77 & 1.1 .23 & 1.1 .24 . & 1.1.25. \\
\hline 1.1 .26 . & $\mathrm{S}$ & 1.1 .27 . & 5.02 & 1.1 .28$. & 1.1 .29$. & 1.1 .30 . \\
\hline \begin{tabular}{|l|}
1.1 .31$. \\
Benlik \\
Kavramının \\
Netliği Ölçeği \\
\end{tabular} & $\begin{array}{c}1.1 .32 . \\
\text { Puan Dağılımı }\end{array}$ & 1.1 .33 . & $\begin{array}{c}1.1 .34 \\
19-60\end{array}$ & 1.1 .35 . & 1.1 .36$. & 1.1.37. \\
\hline 1.1 .38 & $\bar{X}$ & & 45.33 & 1.1 .39 . & 1.1 .40 . & 1.1.41. \\
\hline 1.1 .42 . & $\mathrm{S}$ & 1.1 .43 . & 9.49 & 1.1 .44 . & 1.1 .45 . & 1.1 .46 . \\
\hline \begin{tabular}{|l|}
1.1 .47$. \\
1.1 .48$. \\
Stres Belirtileri Ölçeği
\end{tabular} & $\begin{array}{c}1.1 .49 . \\
\text { Puan Dağılımı }\end{array}$ & 1.1 .50 . & $\begin{array}{l}1.1 .51 \\
43-124\end{array}$ & 1.1 .52 . & 1.1 .53 . & 1.1.54. \\
\hline 1.1.55. & $\bar{X}$ & & 72.48 & 1.1 .56 & 1.1 .57 . & 1.1.58. \\
\hline 1.1.59. & $\mathrm{S}$ & 1.1.60. & 17.21 & 1.1 .61$. & 1.1 .62$. & 1.1.63. \\
\hline \begin{tabular}{|l|}
1.1 .64$. \\
Problem Çözme Envanteri
\end{tabular} & $\begin{array}{c}1.1 .65 . \\
\text { Puan Dağılımı } \\
\end{array}$ & 1.1 .66$. & $\begin{array}{l}1.1 .67 \\
40-131 \\
\end{array}$ & 1.1 .68$. & 1.1 .69$. & 1.1.70. \\
\hline 1.1.71. & $\bar{X}$ & & 82.14 & 1.1 .72$. & 1.1 .73$. & 1.1 .74 . \\
\hline 1.1 .75 & $\mathrm{~S}$ & 1.1 .76 . & 20.60 & 1.1 .77 & 1.1 .78 . & 1.1 .79 . \\
\hline
\end{tabular}

Katılımcıların (erkeklerin) MGİ Ölçeğinden aldığı puanlar 5-25 arasında değişmekte olup, ortalama puan 14.77, standart sapma 5.02; Benlik Kavramının Netliği Ölçeği’nden aldığ puanlar 19-60 arasında değişmekte olup, ortalama puan 45.33, standart sapma 9.49; Stres Belirtileri Ölçeği'nden aldığı puanlar 43-124 arasında değişmekte olup, ortalama puan 72.48 , standart sapma 17.21; Problem Çözme Envanteri'nden aldığ 1 puanlar ise 40-131 arasında değişmekte olup, ortalama puan 82.14, standart sapma 20.60'dır.

Stres Belirtileri Ölçeği 37 maddeden oluşmaktadır ve üç boyutludur. Stres Belirtileri Ölçeği ile kurulan modeli daha iyi hale getirmek için 37 madde üç parsele ayrılmıştır. Parselleme yapmak için öncelikle Tablo 4'te yer alan düzeltilmiş madde toplam korelasyon değerleri hesaplanmıştır. Bu değerler büyükten küçüğe sıralanmış ve daha sonra sırası ile üç parsele, parsellerin toplam korelasyon değerleri birbiri ile dengeli olacak şekilde dağıtılmıştır.

Tablo 3. Ölçeklerin Birbirleriyle Olan Korelasyon Değerleri

\begin{tabular}{|l|l|l|l|l|}
\hline & MGİÖ & BKNÖ & SBÖ & PÇE \\
\hline MGï̈ & - & $\mathbf{1 . 1 . 8 0 .}$ & $\mathbf{1 . 1 . 8 1 .}$ & $\mathbf{1 . 1 . 8 2 .}$ \\
\hline BKNÖ & $-.546^{* *}$ & - & 1.1 .83$. & 1.1 .84$. \\
\hline SBÖ & $.339^{* *}$ & $-.466^{* *}$ & - & 1.1 .85$. \\
\hline PÇE & $.198^{* *}$ & $-.421^{* *}$ & $.375^{* *}$ & - \\
\hline
\end{tabular}

* p< $0.05, * *$ p $<0.01$ Not: BKNÖ: Benlik Kavramının Netliği Ölçeği; MGïÖ: Mutlak Gerçek İhtiyacı Ölçeği; SBÖ: Stres Belirtileri Ölçeği, PÇE: Problem Çözme Envanteri 


\section{Örneklem Grubunda Ölçme Modeli}

Aracı değişkenin etkisini araştırmadan önce çizilen ölçme modeline ait yol katsayıları Tablo 4 'teyer almaktadır.

Tablo 4. Örneklem Grubunda Ölçme Modeli Sonucu Elde Edilen Yol Katsayıları

\begin{tabular}{|l|l|l|l|l|l|}
\hline & Yol & $\mathbf{1 . 1 . 8 6}$. & Standartlaştırılmış Yükler & t-değeri & $\mathrm{R}^{2}$ \\
\hline BKNÖ & $\longrightarrow$ & PÇE & -0.49 & $-7.67^{* * *}$ & 0.24 \\
\hline BKNÖ & $\longrightarrow$ & SBÖ & -0.52 & $-8.68^{* * *}$ & 0.27 \\
\hline MGiÖ & $\longrightarrow$ & PÇE & 0.28 & $3.67^{* * *}$ & 0.07 \\
\hline MGiÖO & $\longrightarrow$ & SBÖ & 0.40 & $5.56^{* * *}$ & 0.16 \\
\hline MGiÖ & $\longrightarrow$ & BKNÖ & -0.67 & $-11.48^{* * *}$ & 0.44 \\
\hline
\end{tabular}

Not: BKNÖ: Benlik Kavramının Netliği Ölçeği; MGiÖ: Mutlak Gerçek İhtiyacı Ölçeği; SBÖ: Stres Belirtileri Ölçeği, PÇE: Problem Çözme Envanteri

Tablo 4.'teyer alan standartlaştırılmış yükler, ölçme modelinde yer alan örtük değiş̧kenler yani ölçekler arasındaki korelasyon katsayılarıdır. Tablodaki değerler incelendiğinde benlik kavramının netliği ile problem çözme değişkenleri, benlik kavramının netliği ile stres belirtileri, MGİ ile problem çözme ve MGİ ile stres belirtileri arasındaki ilişkinin düşük düzey, MGİ ile benlik kavramının netliği değişkeni arasındaki ilişkinin ise orta düzey olduğu görülmektedir. Benlik kavramının netliği ve MGI değiş̧kenlerinin problem çözme değişkeni üzerine etkisi; benlik kavramının netliği ve MGİ değişkenlerinin stres belirtileri değişkeni üzerine etkisi ve MGİ değişkeninin benlik kavramının netliği değişkeni üzerine etkisi 0.05 anlamlılık düzeyinde istatistiksel olarak anlamlıdır. Tabloda yer alan $\mathrm{R}^{2}$ değerleri incelendiğinde problem çözme değişkeninin en çok benlik kavramının netliği, (0.024), stres belirtileri değişkeninin en çok benlik kavramının netliği (0.27) ve benlik kavramının netliği değişkeninin ise en çok MGİ ( 0 . 44) değişkeni tarafından açıklandığı söylenebilir. Kurulan ölçme modeline ilişkin model uyum indekslerine Tablo 5.'te yer verilmiştir.

Tablo 5. Örneklem Grubunda Ölçme Modeli İçin Model Uyum İndeksleri

\begin{tabular}{|l|l|l|l|l|l|l|}
\hline Model & $\chi^{2} / s d$ & RMSEA & CFI & IFI & GFI & SRMR \\
\hline Ölçme Modeli & 1.23 & 0.035 & 0.99 & 0.99 & 0.96 & 0.041 \\
\hline
\end{tabular}

Tablo 5'e göre kurulan ölçme modelinde ki-kare değeri/serbestlik derecesi, CFI, IFI, GFI, RMSEA ve SRMR değerleri iyi uyum göstermektedir $\left(\chi^{2} / s d<2\right.$; RMSEA $<0.05$; CFI $>0.95$;

IFI $>0.95 ; \mathrm{GFI}>0.95 ; \mathrm{SRMR}<0.05$ ). Değerlere göre elde edilen bu modelin veriye iyi uyum gösterdiği söylenebilir.

\section{Örneklem Grubunda Yapısal Model}

Oluşturulan ölçme modeli üzerinden kurulan yapısal modele ilişkin değerler Tablo 6.'da bulunmaktadır. Yapısal model, MGİ değişkeninden benlik kavramının netliği, stres belirtileri ve problem çözme değişkenlerine yol eklenerek oluşturulmuştur. Böylelikle, stres belirtileri ve problem çözme değişkenleri üzerindeki MGİ değişkeninin etkisinin benlik kavramının netliği aracı değişkeni tarafından sağlanıp sağlanmadığı belirlenmek istenmiştir. 
Tablo 6. Örneklem Grubunda Yapısal Model Sonucu Elde Edilen Yol Katsayıları

\begin{tabular}{|l|l|l|l|l|l|}
\hline \multicolumn{2}{|l|}{ Yol } & Standartlaştırılmış Yükler & t-değeri & $\mathrm{R}^{2}$ \\
\hline BKNÖ & $\longrightarrow$ & PÇE & -0.56 & $-4.88^{* * *}$ & 0.31 \\
\hline BKNÖ & $\longrightarrow$ & SBÖ & -0.49 & $-4.54^{* * *}$ & 0.24 \\
\hline MGiÖ & $\longrightarrow$ & PÇE & -0.08 & -0.75 & 0.006 \\
\hline MGiÖ & $\longrightarrow$ & SBÖ & 0.07 & 0.63 & 0.004 \\
\hline MGiÖ & $\longrightarrow$ & BKNÖ & -0.66 & $-7.75^{* * *}$ & 0.43 \\
\hline
\end{tabular}

Not: BKNÖ: Benlik Kavramının Netliği Ölçeği; MGiÖ: Mutlak Gerçek İhtiyacı Ölçeği; SBÖ: Stres Belirtileri Ölçeği, PÇE: Problem Çözme Envanteri

Elde edilen değerlere göre MGİ değişkeninin stres belirtileri değişkeni ve MGİ değişkeninin problem çözme değişkeni üzerine etkisi istatiksel olarak anlamlı değildir. Bu ilişkilerin oluşturduğu yolların modelden kaldırılması modelin iyileştirilmesine katkı sağlayabilir.

Kurulan yapısal modelde elde edilen model uyum indeksleri Tablo 7.'de yer almaktadır.

Tablo 7. Örneklem Grubunda Yapısal Model İçin Uyum İndeksleri

\begin{tabular}{|l|l|l|l|l|l|l|}
\hline Model & $\chi^{2} / s d$ & RMSEA & CFI & IFI & GFI & SRMR \\
\hline Yapisal Model & 1.38 & 0.044 & 0.99 & 0.99 & 0.95 & 0.058 \\
\hline
\end{tabular}

Tablo 7. incelendiğinde, yapısal modele ait değerlerden ki kare değeri/ serbestlik derecesi, RMSEA, CFI, IFI, GFI iyi uyum, SRMR değeri ise kabul edilebilir uyum göstermektedir $\left(\mathrm{x}^{2} /\right.$ $\mathrm{sd}<2$; RMSEA $<0$. 05; CFI $>0.95$; IFI $>0.95 ; \mathrm{GFI} \geq 0.95$; $\mathrm{SRMR}<0.08$ ).

MGI değişkeninden stres belirtileri değişkenine giden yolun silinmesi ile oluşan ki-kare farkına ait değer modelde anlamlı farkın oluşmadığını göstermektedir $(0.39<3.84)$. Eğer 1 df' lik 3.84' lük chi square'de fark yoksa df'si yüksek olan model tercih edileceğinden yolların silinmiş olduğu model tercih edilir. MGİ değişkeninden stres belirtileri değişkenine giden yolun silinmesi ile elde edilen model uyum indeksleri Tablo 8.'deyer almaktadır.

Tablo 8. Örneklem Grubunda MGi Değişkeninden Stres Belirtileri Değişsenine Giden Yolun Silinmesi ile Elde Edilen Yapısal Model İçin Uyum İndeksleri

\begin{tabular}{|l|l|l|l|l|l|l|}
\hline Model & $\chi^{2} / s d$ & RMSEA & CFI & IFI & GFI & SRMR \\
\hline Yapisal Model & 1.36 & 0.043 & 0.99 & 0.99 & 0.95 & 0.057 \\
\hline
\end{tabular}

Tablo 8. incelendiğinde, yapısal modele ait değerlerden ki kare değeri/ serbestlik derecesi, RMSEA, CFI, IFI, GFI iyi uyum, SRMR değeri ise kabul edilebilir uyum göstermektedir $\left(\mathrm{x}^{2} /\right.$ $\mathrm{sd}<2$; RMSEA $<0$. 05; CFI $>0.95 ;$ IFI $>0.95$; GFI $\geq 0.95$; $\mathrm{SRMR}<0.08$ ).

Benzer şekilde, MGİ değişkeninden problem çözme değişkenine giden yolun silinmesi ile oluşan ki-kare farkına ait değer de modelde anlamlı farkın oluşmadığını göstermektedir $(0.56<3.84)$. Eğer 1 df' lik 3.84' lük chi square' da fark yoksa df'si yüksek olan model tercih edileceğinden yolların silinmiş olduğu model tercih edilir. MGİ değişkeninden problem çözme değişkenine giden yolun silinmesi ile elde edilen model uyum indeksleri Tablo 9.'da yer almaktadir. 
Tablo 9. Örneklem Grubunda MGİ Değişkeninden Problem Çözme Değişkenine Giden Yolun Silinmesi ile Elde Edilen Yapısal Model İçin Uyum İndeksleri

\begin{tabular}{|l|l|l|l|l|l|l|}
\hline Model & $\chi^{2} / s d$ & RMSEA & CFI & IFI & GFI & SRMR \\
\hline Yapisal Model & 1.34 & 0.042 & 0.99 & 0.99 & 0.95 & 0.060 \\
\hline
\end{tabular}

Tablo 9. incelendiğinde, yapısal modele ait değerlerden ki kare değeri/ serbestlik derecesi, RMSEA, CFI, IFI, GFI iyi uyum, SRMR değeri ise kabul edilebilir uyum göstermektedir $\left(\mathrm{x}^{2} /\right.$ $\mathrm{sd}<2$; RMSEA $<0.05 ; \mathrm{CFI}>0.95 ; \mathrm{IFI}>0.95 ; \mathrm{GFI} \geq 0.95$; $\mathrm{SRMR}<0.08)$.

Erkeklerde MGİ değişkeninin stres belirtileri ve problem çözme üzerindeki etkisinin benlik kavramının netliği aracı değişkeni tarafından sağlanıp sağlanmadığını ölçmek amacıyla kurulan modelde, benlik kavramının netliği değişkeninin tam aracılık rolünün olduğu görülmektedir (bkz. Şekil 1).

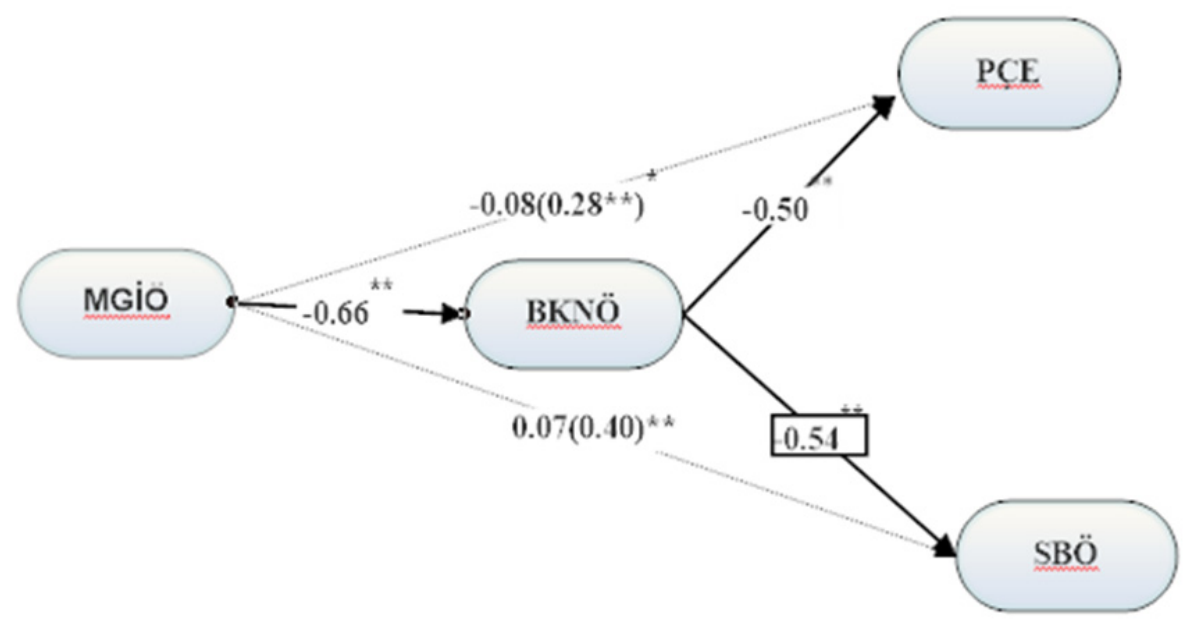

Fig. 1. Örneklem Grubunda Elde Edilen Yeni Yapısal Model

\section{Sonuçlar}

\section{Erkeklerde MGİ ile Benlik Kavramının Netliği, Problem Çözme ve Stres Belirtileri Değişkenleri Arasındaki İliş̧i}

Düzenlenen çalışmanın alt problemlerinden biri, erkeklerde MGİ'nin problem çözme, stres belirtileri ve benlik kavramının netliği değişkenlerini yordayıp yordamadığıdır. Bulgular incelendiğinde, MGİ ile problem çözme ve MGİ ile stres belirtileri arasındaki ilişkinin pozitif yönde ve düşük düzeyde, MGİ ile benlik kavramının netliği değişkeni arasındaki ilişkinin ise negatif yönde ve orta düzeyde olduğu görülmektedir (Tablo 6.). Tablo incelendiğinde MGİ değişkeni ile problem çözme değişkeni arasında pozitif yönde ilişki olduğu görülmektedir; ancak problem çözme envanterinden alınan puanların artmasının problem çözme konusunda başarısız olmayı ifade etmesi nedeniyle MGİ artıça problem çözme becerisinin azalacağı söylenebilir. Tabloda yer alan $\mathrm{R}^{2}$ değerleri incelendiğinde benlik kavramının netliği değişkeninin en çok MGI $(0.44)$ değişkeni tarafından açıklandığı söylenebilir.

Duval ve Wicklund'a göre (1972), kendine odaklanma gerçek benlik ile ideal benlik arasındaki algılanan farklılıkların artmasını sağlamakta ve mevcut duygu durumun bozulmasına yol açmaktadır. Kişinin kendisine odaklandığında eksik yönlerini fark edebileceği ve bu nedenle 
olmak istediği ben ile sahip olduğu ben arasında farkl1lık olduğunu anlayabileceği savunulmaktadır. Olmak istediği bene sahip olamamanın ve ideallerine ulaşamamanın kişide stres yaratabileceği ve bu durumun duygu durumunu olumsuz yönde etkilediği düşünülmektedir. Kişinin olmak istediği bene sahip olamamasının kişide yetersizlik hissi yaratabileceği düşünülebilir. Bu durumunda, bireylerde benlik kavramının netliğinin düşmesine yol açabilir ve duygu durumu olumsuz yönde etkileyebilir. Bunlara paralel olarak Akcan $(2013 ; 2018)$ tarafından düzenlenen çalışmalarda da, MGİ ile benlik kavramının netliği değişkeni arasında negatif yönde bir ilişki olduğu bulunmuştur. Bu doğrultuda, MGİ'nin artması durumunda benlik kavramının netliğinin azalacağı görülmektedir.

Bunların yanı sıra, yüksek seviyedeki kurgulamaların (soyut düşüncelerin), farklı durumlara karşı genellemeler yapma eğilimini yansıttığı savunulmaktadır (Forster ve Higgins, 2005). Olumsuz durumlar karşısında yapılan soyut kurgulamaların bireylerin olumsuz aşırı genellemelerini artırdığı, tek bir başarısızlığın her durumda geçerli kişisel bir yetersizlik olarak açıklanmasına neden olduğu ve bu olumsuz genellemelerin de depresyon gelişimine yol açtığ belirtilmektedir (Hamilton et al. 1993). Olumsuz bilgiyle karşılaşılması durumunda, somut kurgulamaların olumsuz aşırı genellemelerin azalmasını sağlayarak daha uyumlu bir rol oynadığı ve somut yapıların, olumsuz olayların nedenlerinin geçici ve kontrol edilebilir olarak yorumlanmasını sağladığı savunulmaktadır. Ayrıca Philippot, Baeyens ve Douilliez (2006), duygusal bir olayı belirli bir detayı ile hatırlamanın daha genel bir düzeyde hatırlamaktan daha az duygusal tepki yarattığını savunmaktadır. MGİ de, soyut düşünce tarzını ve aşırı genelleme yönelimini içerdiğinden MGİ yüksek olan bireylerde daha fazla stres belirtisi görüleceğini ifade etmek mümkündür.

Bunlara ek olarak, soyut düşünme tarzının problem çözme yeteneği üzerinde olumsuz etkisi olduğu savunulmaktadır (Watkins 2008). Şimşek (2013), yüksek MGI'nin her duruma ilişkin temel bir açıklama veya anlam bulmak açısından zarar verici bir ihtiyaç olduğunu belirtmekte ve kişiler arası ve kişisel seviyede problem çözümünü engellediğini savunmaktadır. Bunlara paralel olarak Nisbet ve Wilson (1977) da, yüksek seviyedeki temsillere odaklanmanın kişilerdeki durumlara genel teorilerle veya yaygın hesaplarla yaklaşma eğilimini artırdığını ve iç görüyü azalttığını belirtmektedir. Her olayın kendine özgü bir dinamiği olması nedeniyle aşırı genelleme yapma eğiliminin bireylerin problem çözme becerileri üzerinde olumsuz etkiye sahip olacağı düşünülebilir. Bu doğrultuda, soyut düşünme tarzını ve aşırı genelleme eğilimini barındıran MGİ'nin problem çözmede işlevselliği azalttığı görülmektedir.

$\mathrm{Bu}$ bağlamda, MGİ soyut düşünme tarzını içerdiğinden stres belirtileri değişkeni ile de pozitif yönde ilişkili olduğu düşünülebilir. Kendisini daha iyi tanımak amacıyla kendine yönelik kesin, sabit, her durumda geçerli bilgiler edinme arayışında olan; yani yüksek MGİ taşıyan bireylerin benliklerine ilişkin elde ettikleri çelişkili bilgiler neticesinde benlik kavramlarının netliğinin düşeceği söylenebilir. Elde edilen çelişkili bilgilerin bireylerde stres yarattığını da görmek mümkündür. Bu nedenle MGİ ile benlik kavramının netliği arasında negatif yönde ilişki olduğu görülmektedir. Ayrıca, MGİ'nin soyut düşünce tarzını içerdiğinden problem çözme becerilerini olumsuz yönde etkilediği, MGİ ile problem çözme becerileri arasında negatif yönde ilişki olduğunu ifade etmek yanlış olmaz. Bu doğrultuda, literatürde yer alan çalışmaların bu araştırmanın bulgularına katkı sağladığı, desteklediği ve MGİnin benlik kavramının netliği ile problem çözme değişkenlerini negatif, stres belirtileri değişkenini ise pozitif yönde yordadığ görülmektedir. 


\section{Erkeklerde Benlik Kavramının Netliği ile Problem Çözme ve Stres Belirtileri Değişkenleri Arasındaki İlişki}

Düzenlenen çalışmanın erkeklere ilişkin alt problemlerinden bir diğeri de, erkeklerde benlik kavramının netliği değişkeninin problem çözme ve stres belirtileri değişkenlerini yordayıp yordamadığıdır. Bulgular incelendiğinde, benlik kavramının netliği ile problem çözme değişkeni ve benlik kavramının netliği ile stres belirtileri değişkeni arasındaki ilişkinin orta düzey olduğu görülmektedir (Tablo 6.). Tabloda yer alan $\mathrm{R}^{2}$ değerleri incelendiğinde problem çözme değişkeninin en çok benlik kavramının netliği $(0.024)$ ve stres belirtileri değişkeninin de en çok benlik kavramının netliği (0.27) değişkeni tarafından açıklandığı görülmektedir.

Şimdiye kadar düzenlenen çalışmalar incelendiğinde, benlik kavramına ilişkin karmaşa yaşayan bireylerde davranış seçiminde kendini rehber edinmeyi içeren bir strateji olan karar verme yönteminin kullanımının azaldığı görülmektedir (Setterlund \& Niedenthal 1993). Bu bağlamda, benlik kavramının netliği düşük olan bireylerin problem çözme konusunda daha işlevsel bir strateji olan problem çözme yöntemini kullanma konusunda daha başarısız oldukları söylenebilir. Ayrıca Engin (2004) düzenlediği çalışmada, benlik kavramının netliği yüksek olan bireylerin kendi yeteneklerinin farkında olduğunu ve böylece davranışlarını sosyal ortamın taleplerine göre düzenlemede daha başarılı olduklarını ve kaygı seviyelerinin daha düşük olduğunu gözlemlemiştir. Benlik kavramının netliği yüksek olan bireylerin kendilerine ilişkin

farkındalıklarının ve adaptasyon becerilerinin yüksek olması sayesinde sosyal ortamlara ilişkin karşılaştıkları problemler karşısında çözüm üretmede daha başarılı olacakları savunulmaktadır (Akcan 2018).

Bunlara ek olarak Bechtoldt, de Dreu, Nijstad ve Zapf (2010) tarafından düzenlenen çalışmada, benlik kavramının netliği yüksek olan bireylerin problem çözmede daha aktif oldukları, önleyici tedbirler aldıkları ve daha işbirlikçi yöntemler kullandıkları görülmüsstür. Yazarlara göre, benlik kavramının netliği yüksek olan bireyler kendilerine ilişkin olumsuz bilgilerle daha az meşgul olurlar ve sosyal çatışmaları egoları için tehdit olarak algılama eğilimleri daha düşüktür Benzer şekilde von Collani ve Werner (2005) de, benlik kavramının netliğinin problem çözme ile pozitif, kaçınma ve yok sayma ile ise negatif yönde ilişkili olduğunu savunmaktadır.

Bunların yanı sıra, benlik kavramının netliğinin agresyon ile negatif yönde ilişkili olduğu savunulmaktadır (Stucke \& Sporer 2002). Schwartz, Cote ve Arnett (2005), benlik kavramının netliğinin benlik saygısı ve yaşam doyumu gibi olumlu değişkenlerle ilişkili olduğunu belirtmektedir. Ayrıca, benlik kavramının netliğinin kaygı ve depresyon gibi stres belirtilerine karşı koruyucu görevinin olduğu savunulmaktadır (Schwartz 2007). Schwartz, Zamboanga, Weisskirch ve Rodriguez (2009) de, benlik kavramına ilişkin karmaşa yaşamanın strese yol açtığını belirtmektedir.

Literatürde yer alan çalışmalar incelendiğinde, araştırma bulgularının bu çalışmanın sonuçlarını desteklediği görülmektedir. Benlik kavramının netliği değişkeninin stres belirtileri değişkeni ile negatif, problem çözme becerileri ile pozitif yönde ilişkili olduğu görülmektedir. Bu bağlamda, benlik kavramının netliği yüksek olan bireylerin daha az stres belirtisi göstereceği ve problem çözmede daha etkin olacağı söylenebilir.

\section{Erkeklerde Benlik Kavramının Netliği Değişkeninin MGí ile Problem Çözme ve Stres Belirtileri Değişkenleri Arasındaki İlişkideki Aracılık Rolü}

Araştırmanın bir diğer temel amacı, erkeklerde MGİ değişkeninin stres belirtileri ve problem çözme değişkenleri üzerindeki etkisinin benlik kavramının netliği aracı değişkeni tarafından sağlanıp sağlanmadığını belirlemektir. Bu doğrultuda, MGİ değişkeninden benlik kavramının 
netliği, stres belirtileri ve problem çözme değişkenlerine yol eklenerek yapısal model oluşturulmuştur. Yapısal eşitlik modellemesinden elde edilen bulgular, MGİ değişkeninin stres belirtileri değişkeni ve MGİ değişkeninin problem çözme değişkeni üzerine etkisinin istatiksel olarak anlamlı olmadığını göstermektedir. Bu ilişkilerin oluşturduğu yolların modelden kaldırılmasının modelin iyileştirilmesine katkı sağladığı söylenebilir. Bu bağlamda, erkeklerde MGİ değişkeninin stres belirtileri ve problem çözme değişkenleri üzerindeki etkisinin benlik kavramının netliği aracı değişkeni tarafından sağlanıp sağlanmadığını ölçmek amacıyla kurulan modelde benlik kavramının netliği değişkeninin tam aracılık rolünün olduğu görülmektedir (Tablo 8).

Düzenlenen çalışmalar incelendiğinde, kendine odaklanmanın zihinsel sağlık üzerinde olumsuz etkisinin olduğunun savunulduğu dikkat çekmektedir (Watkins, 2008). Ancak Şimşek (2013) tarafından düzenlenen çalışmada, MGİ değişkeninin etkisinin kontrol edilmesi durumunda kendine odaklanma ile benlik kavramının netliği, kaygı ve depresyon arasındaki ilişkinin yönünün değiştiği görülmüştür. Bu bağlamda, MGİ değişkeninin benlik kavramının netliğinin düşmesine, kayg1 ve depresyonun ise artmasına yol açtı̆̆ 1 söylenebilir. MGI'nin benlik kavramının netliği ile negatif, kaygı ve depresyon gibi olumsuz zihinsel sağlık belirtileri ile ise pozitif yönde ilişki gösterdiği görülmektedir.

Bunların yanı sıra Schwartz ve arkadaşları (2011) tarafından düzenlenen çalışmada, benlik kavramının netliği değişkeninin stres değişkeni ile negatif yönde ilişkili olduğu bulunmuştur. Benzer şekilde Crocetti, Rubini ve Meeus (2008) da, benlik kavramının netliğinin psikolojik iyi oluş ile pozitif, stres ile ise negatif yönde ilişkili olduğunu savunmaktadır. Aynı zamanda Campbell, Assanand ve Di Paula (2003) da, benlik kavramının netliğinin kaygı ve depresyon gibi stres belirtilerine karşı koruyucu görevi olduğunu savunmaktadır.

Bunlara ek olarak, net ve tutarlı benlik kavramına sahip bireylerin olumsuz geri bildirimlerle karşılaştıklarında daha yapıcı oldukları savunulmaktadır (de Dreu \& Van Knippenberg 2005). Pruitt (1998) de, çatışmalı durumlarda pasif başa çıkma yöntemleri kullanmanın benlik kavramının netliğinin düşük olması, önleyici tedbir almanın ise benlik kavramının netliğinin yüksek olması ile ilişkili olduğunu vurgulamaktadır. Bunlara paralel olarak Bechtoldt, de Dreu, Nijstad ve Zapf (2010) da, benlik kavramının netliği yüksek olan bireylerin pasif başa çıkma stratejileri yerine problem çözücü daha işlevsel başa çıkma yöntemleri kullandığını belirtmektedir.

Ayrıca, MGI'nin davranışların arkasındaki nedenleri arama boyutunun kişilerin yaşamında önemli bir rolü olduğu düşünülmektedir. Nisbett ve Wilson (1977), kişilerin davranışlarının nedenlerini bilişsel süreçlerine ulaşamadıkları için anlayamadıklarını söylemiştir. Yazarlar, kişilerin tam bir erişime sahip olduklarında daha sonra bir davranışı yaparken izledikleri süreç hakkında doğru bilgi verebileceklerini savunmaktadır. Ancak Smith ve Miller (1978), tek başına bilişsel süreçlere erişmenin kişinin nedensellik içeren soruları cevaplayabilmesi anlamına gelmediğini belirtmekte; fakat Nibett ve Wilson ile (1977) sürecin doğru aktarılması konusunda aynı görüşü paylaşmaktadırlar. Sabini ve Silver'a göre (1981), süreci doğru aktarabilmek için kişinin raporlamaya ne zaman başlayacağını, raporun neleri içereceğini bilmesi gerekir ve bir başlama kıstası olmalıdır. Ancak yazarlara göre, yalnızca başlama kıstasının olması da yeterli değildir. Ayrıca, süreci doğru aktarabilmek için, sadece içsel süreçleri izlemek yerine izlenecek basamaklarla etraftaki diğer olayların ilişkisini bilmek gerekir (Sabini \& Silver 1981). Bilişsel süreçler için kuralların önemli belirleyiciler olduğu görülmektedir.

Davranışların arkasında yatan nedenleri aramak MGİ değişkeninin alt boyutlarından biridir. Bireyler, davranışlarının arkasında yatan nedenleri anlayabildiğinde kendilerini olumsuz yönde etkileyen, onlara sıkıntı yaratan, çevreleriyle uyumlarının bozulmasına yol açan davranışlarını 
değiştirmede daha etkin rol alacaktır (Akcan 2013). Davranışlarının arkasındaki nedenleri kavrayan bireylerin karşılaştıkları problemler karşısında kendini düzenleme konusunda ve problem çözümünde daha başarılı olacakları söylenebilir. Çünkü; sergiledikleri davranışların nedenlerini bilen, kendini tanıyan; yani MGİ ve benlik kavramının netliği yüksek olan bireylerin problemlere karşı farkındalıklarının yüksek olacağı ve aktif problem çözme becerileri kullanabilecekleri düşünülebilir. Bu nedenle, davranışların arkasındaki nedenleri bulmanın kişinin hayatına olumlu etkilerinin olduğu söylenebilir. Bu bağlamda, MGİ yüksek olan bireylerin kendilerine yönelik net ve tutarlı bilgiler edinmelerinin ve benlik kavramlarının yüksek olmasının neticesinde problem çözme becerilerinin artacağı anlaşılmaktadır.

Şimdiye kadar düzenlenen araştırmaların bulguları ile bu çalışmadan elde edilen verilerin birbirine paralellik gösterdiği görülmektedir. Erkeklerde MGì değişkeninin stres belirtileri ile pozitif, benlik kavramının netliği ve problem çözme değişkenleri ile negatif yönde ilişki gösterdiği görülmektedir. Ancak, problem çözme ölçeğinden alınan puanların düşmesinin problem çözmede daha başarılı olmayı yansıtması nedeniyle MGİ artıkça problem çözme yeteneğinin de artacağı görülmektedir. Erkeklerde MGİ değişkeninin problem çözme becerileri üzerindeki olumsuz etkisinin bireylerdeki benlik kavramının netliğinin artması durumunda olumlu yönde değişeceği görülmektedir. MGİ yüksek olan bireylerin benlik kavramının netliğinin düşük olması nedeniyle stres belirtilerinin artığı; ancak benlik kavramının netliğinin artması durumunda problem çözmede daha etkin olacakları ve stres belirtilerinin azalacağı söylenebilir. Bu doğrultuda erkek bireylerde MGİ değişkeninin stres belirtileri ve problem çözme becerileri değişkenleri üzerine olan etkisinde benlik kavramının netliği değişkeninin aracı rolü oynadığı anlaşılmaktadır.

\section{Sinırlılıklar}

1. Araştırmanın örneklemini İstanbul ve Kocaeli illerinde yaşayan en az lise ve üniversite düzeyinde eğitim görmüş, erkek bireyler oluşturmaktadır. Ülkemizin farklı bölgelerinde yaşayan ve farklı eğitim düzeylerinde eğitim görmüş bireylerde farklı sonuçlar alınabileceği düşünülebilir. Farklı demografik özelliklere sahip katılımc1larla yapılacak çalışmalar kültürel farklılaşmanın etkilerini ortaya koyabilir.

2. Bu çalışmada sadece erkek bireylere yer verilmiştir. Daha kapsamlı olarak düzenlenen çalışmalarda kadın ve erkeklerin çeşitli boyutlardaki benzerlik ve farklılaşmaları incelenebilir.

3. Araştırma verileri, kullanılan ölçme araçlarından toplanacak verilerle sınırlıdır.

4. Araştırma, amaçlardaki sorularla sınırlıdır.

5. Araştırma, yapılan literatür taramasıyla sınırlıdır. 


\section{KAYNAKÇA}

Akcan (2018). Erkek Eşcinsellerde Benlik Kavramının Netliği ve Mutlak Gerçek İhtiyacı Değişkenleri ile Problem Çözme ve Stres Belirtileri Değiş̧kenleri Arasindaki Illişkinin İncelenmesi. Doktora Tezi. İstanbul 2018.

Akcan G. (2013). Mutlak Gerçek İhtiyacı Ölçeği Gelişstirme Çalışması. Yüksek Lisans Tezi. İstanbul Arel Üniversitesi, İstanbul 2013.

Bar-Anan Y., Wilson T. D. \& Gilbert D. T. (2009). "The Feeling of Uncertainty Intensifies Affective Reactions". Emotion (2009) 123.

Bechtoldt,M. N., de Dreu C. K., Nijstad B. A. \& Zapf D. (2010). "Self Concept Clarity and the Management of Social Conflict". Journal of Personality (2010) 539-574.

Berman S. L., Montgomery M. J. \& Kurtines W. M. (2004). "The Development and Validation of a Measure of Identity Distress". Identity: An International Journal of Theory and Research (2004) 1-8.

Buhr K. \& Dugas M. J. (2002). "The Intolerance of Uncertainty Scale: Psychometric Properties of the English Version". Behaviour Research and Therapy (2002) 931-945.

Campbell J. D. (1990). "Self-Esteem and Clarity of The Self-Concept". Journal of Personality and Social Psychology (1990) 538.

Campbell J. D., Assanand S. \& Di Paula A. (2003). "The Structure of the Self Concept and Its Relation to Psychological Adjustment". Journal of Personality (2003)115-140.

Campbell J. D., Trapnell P. D., Heine S. J. \& Katz I. M. (1996). "Self-Concept Clarity:Measurement, Personality Correlates, and Cultural Boundaries". Journal of Personality and Social Psychology (1996) 141-156.

Campbell J. D., Trapnell P. D., Heine S. J., Katz I. M., Lavallee L. F. \& Lehman D. R. (1996). "SelfConcept Clarity: Measurement, PersonalityCorrelates, and Cultural Boundaries". Journal of Personality and SocialPsychology (1996) 141.

Cass V. C. (1979). "Homosexuality Identity Formation: A Theoretical Model". Journal of Homosexuality (1979) 219-235.

Cohen L. H., Gunthert K. C., Butler A. C., O’Neill S. C. \& Tolpin L. H. (2005). "Daily Affective Reactivity as a Prospective Predictor of Depressive Symptoms". Journal of Personality (2005) 1687-1714.

Conley J. J. (1984). "Longitudinal Consistency Of Adult Personality: Self Reported Psychological Characteristics Across 45 Years". Journal of Personality and Social Psychology (1984) 1325.

Constantino M. J., Wilson K. R., Horowitz L. M. \& Pinel E. C. (2006). "The Direct and Stress Buffering Effects of Self-Organization on Psychological Adjustment". Journal of Social and Clinical Psychology (2006) 333-360.

de Dreu C. K. \& van Knippenberg D. (2005). "The Possessive Self as a Barrier toConflict Resolution: Effects of Mere Ownership, Process Accountability, and Self-Concept Clarity on Competitive Cognitions and Behavior". Journal of Personality and Social Psychology (2005) 345.

Duval S. \& Wicklund R. A. (1972). A Theory of Objective Self Awareness. 1972.

Ed D., Suh E. M., Lucas R. E. \& Smith H. L. (1999). "Subjective Well-Being: Three Decades of Progress". Psychological Bulletin (1999) 276-302.

Engin E. (2004). The Relationship Between Self-Concept Structure and Behavioral Flexibility: A Model Relating Cognitive Structures to Behavioral Patterns. Doctoral Dissertation. Middle East Technical University, Ankara 2004.

Forster J. \& Higgins E. T. (2005). "How Global Versus Local Perception Fits Regulatory Focus". Psychological Science (2005) 631-636.

Franks H. M. \& Roesch S. C. (2006). "Appraisals and Coping in People Living with Cancer: A MetaAnalysis". Psycho-Oncology (2006) 1027-1037.

Hamilton J. C., Greenberg J., Pyszczynski T. ve Cather C. (1993). "A Self Regulator Perspective on Psychopathology and Psychotherapy". Journal of Psychotherapy Integration (1993) 205.

Hanna F. J. (2002). Therapy With Difficult Clients: Using The Precursors Model to Awaken Change. Washington 2002 . 
Heppner P. P. \& Petersen C. H. (1982). "The Development and Implications of Apersonal ProblemSolving Inventory”. Journal of Counseling Psychology (1982) 66.

Hovardaoğlu S. (1997). "Stres Belirtileri ile Durumsal ve Sürekli KaygınınYordanması". Kriz Dergisi (1997) 127-135.

Kernis M. H., Paradise A. W., Whitaker D. J., Wheatman S. R. \& Goldman B. N. (2000). "Master of One’s Psychological Domain? Not Likely If One's Self-Esteem Is Unstable”. Personality and Social Psychology Bulletin (2000) 1297-1305.

Lee-Flynn S. C., Pomaki G., Delongis A., Biesanz J. C. \& Puterman E. (2011). "Daily Cognitive Appraisals, Daily Affect, and Long-Term Depressive Symptoms: The Role of Self Esteem and Self Concept Clarity in the Stress Process". Personality and Social Psychology Bulletin (2011) 255-268.

Leite C. \& Kuiper N. A. (2008). "Client Uncertainty and the Process of Change Psychotherapy: The Impact of Individual Differences in Self Concept Clarity and Intolerance of Uncertainty". Journal of Contemporary Psychotherapy (2008) 55-64.

Lewandowski Jr. G. W., Nardone N. \& Raines A. J. (2010). "The Role of Self-Concept Clarity in Relationship Quality". Self and Identity (2010) 416-433.

Luyckx K., Schwartz S. J., Berzonsky M. D., Soenens B., Vansteenkiste M., Smits I. \& Goossens L. (2008). "Capturing Ruminative Exploration: Extending the Four-Dimensional Model of dentity Formation in Late Adolescence”. Journal of Research in Personality (2008) 58-82.

Malhotra N. K. (2004). Marketing Research an Applied Orientation. New Jersey $2004^{4}$.

Nezlek J. B. \& Plesko R. M. (2001). "Day-to-Day Relationships Among Self Concept Clarity, SelfEsteem, Daily Events, and Mood". Personality and Social Psychology (2001) 201-211.

Nisbett R. E. \& Wilson T. D. (1977). "Telling More Than We Can Know: Verbal Reports on Mental Processes". Psychological Review (1977) 231- 259.

Özdamar K. (1999). Paket Programlar ile Istatistiksel Veri Analizi. Eskişehir 1999.

Philippot P., Baeyens C. \& Douilliez C. (2006). "Specifying EmotionalInformation: Regulation of Emotional Intensity Via Executive Processes". Emotion (2006) 560.

Pinquart M. \& Sörensen S. (2001). "Gender Differences in Self-Concept and Psychological Well-Being in Old Age: A Meta-Analysis”. The Journals of Gerontology Series B: Psychological Sciences And Social Sciences (2001) 195-213.

Prochaska J. O. \& Diclemente C. C. (1983). "Stages And Processes of Selfchange in Smoking: Toward an Integrative Model of Change”. Journal of Consulting Clinical Psychology (1983) 390-395.

Ritchie T. D., Sedikides C., Wildschut T., Arndt J. \& Gidron Y. (2011). "Self Concept Clarity Mediatest the Relation Between Stress and SubjectiveWell Being”. Self and Identity (2011) 493-508.

Sabini J. \& Silver M. (1981). "Introspection and Causal Accounts". Journal of Personality and Social Psychology (1981) 171-179.

Schwartz S. J. (2007). "The Structure of Identity Consolidation: Multiple Correlated Constructs or One Superordinate Construct”. Identity: An International Journal of Theory and Research (2007) 27-49.

Schwartz S. J., Côté J. E.\& Arnett J. J. (2005). "Identity and Agency In Emerging Adulthood Two Developmental Routes in the Individualization Process". Youth \& Society (2005) 201-229.

Schwartz S. J., Zamboanga B. L., Weisskirch R. S. \&Rodriguez L. (2009). "The Relationships of Personal and Ethnic Identity Exploration to Indices of Adaptive and Maladaptive Psychosocial Functioning". International Journal of Behavioral Development (2009) 131-144.

Setterlund M. B. \& Niedenthal P. M. (1993). “'Who Am I? Why Am I Here?' Self-Esteem, Self Clarity, and Prototype Matching”. Journal of Personality and Social Psychology (1993) 769.

Slotter E. B., Gardner W. L. \& Finkel E. J. (2010). "Who Am I Without You? The Influence of Romantic Breakup on the Self-Concept". Personality and Social Psychology Bulletin. 36/2 (2010) 147-160.

Smith E. R. \& Miller F. D. (1978). Limits on Perception of Cognitive Processes: A Reply to Nisbett And Wilson. 1978.

Smith M., Wethington E. \& Zhan G. (1996). "Self-Concept Clarity and Preferred Coping Styles”. Journal of Personality (1996) 407-434. 
Stöber J., Tepperwien S. \& Staak M. (2000). "Worrying Leads to Reduced Concreteness of Problem Elaborations: Evidence for the Avoidance Theory of Worry". Anxiety Stress and Coping (2000) 217-227.

Stucke T. S. \& Sporer S. L. (2002). "When a Grandiose Self-Image Is Threatened: Narcissism and SelfConcept Clarity as Predictors of Negative Emotions and Aggression Following Ego Threat". Journal of Personality (2002) 509-532

Swann W. B., Pelham B. W. \& Chidester T. R. (1988). "Change Through Paradox: Using Self Verification to Alter Beliefs". Journal of Personality and Social Psychology (1988) 268.

Şimşek Ö. F. (2007). Yapısal Eşitlik Modellemesine Giriş: Temel İlkeler ve LISREL Uygulamaları. Ankara 2007.

Şimşek Ö. F. (2013). "Self-Absorption Paradox Is Not Paradox: Illuminating the Dark Side of Self Reflection". International Journal of Psychology (2013) 1109-1121.

Treadgold R. (1999). "Transcendent Vocations: Their Relationship to Stress,Depression, and Clarity of Self-Concept". Journal of Humanistic Psychology (1999) 81-105.

von Collani G. \& Werner R. (2005). "Self-Related and Motivational ConstructsasDeterminants of Aggression: An Analysis and Validation of a German Version of the Buss Perry Aggression Questionnaire". Personality and Individual Differences (2005) 1631-1643.

Watkins E. \& Teasdale J. D. (2004). "Adaptive and Maladaptive Self-Focus in Depression". Journal of Affective Disorders (2004) 1-8.

Watkins E. R. (2008). "Constructive and Unconstructive Repetitive Thought". Psychological Bulletin (2008) 163-206.

Watson D., David J. P. \& Suls J. (1999). "Personality, Affectivity, and Coping". Coping: The Psychology of What Works (1999) 119-14.

Zhou X., Sedikides C., Wildschut T. \& Gao D. G. (2008). "Counteracting Loneliness on the Restorative Function of Nostalgia”. Psychological Science (2008) 1023-1029. 
